\title{
Lead content of Paratenuisentis ambiguus (Acanthocephala), Anguillicola crassus (Nematodes) and their host Anguilla anguilla
}

\author{
Bernd Sures ${ }^{1}$, Horst Taraschewski ${ }^{1}$, Ewald Jackwerth ${ }^{2}$ \\ ${ }^{1}$ Zoologisches Institut - Ökologie, Universität Karlsruhe (T.H.), Geb. 30.43, D-76128 Karlsruhe, Germany \\ ${ }^{2}$ Arbeitsgruppe für Mikro- und Spurenanalyse, Ruhr-Universität Bochum, D-44870 Bochum, Germany
}

\begin{abstract}
Adults of the acanthocephalan Paratenuisentis ambiguus and the nematode Anguillicola crassus were collected from eels from the river Weser, Germany, and examined for lead levels. In addition to these parasites, different fish tissues (liver, bile and intestine) were also analysed for lead, using electrothermal atomic absorption spectrometry. P. ambiguus was found to contain the highest amounts of lead. The mean lead level in A. crassus was much lower, resembling the values obtained from eel tissues. The accumulation capacity of $P$. ambiguus was about 100 times higher than that of $A$. crassus. Thus, $P$. ambiguus can be considered a rather sensitive indicator of lead in aquatic ecosystems.
\end{abstract}

KEY WORDS: Anguillicola crassus - Paratenuisentis ambiguus Anguilla anguilla Lead Atomic absorption spectrometry

\section{INTRODUCTION}

The nematode Anguillicola crassus (Dracunculoidea, Anguillicolidae) and the acanthocephalan Paratenuisentis ambiguus (Tenuisentidae) are eel-specific helminths (Taraschewski et al. 1987) recently introduced into Europe. Considerable information is available on the biology of A. crassus (e.g. Taraschewski et al. 1987 , Polzer \& Taraschewski 1993, Nagasawa 1994) and there are also several studies on $P$. ambiguus (e.g. Samuel \& Bullock 1981, Taraschewski 1989, Hamers et al. 1991, 1992, Taraschewski et al. 1992).

There is a developing body of literature (e.g. Möller 1987, Khan \& Thulin 1991, Koskivaara \& Valtonen 1992, Sures et al. 1994a, b) dealing with the interrelation between pollution and fish parasites, but there are just a few comparative, quantitative investigations about the heavy metal content of fish parasites and their hosts. Sures et al. (1994a, b) reported very high lead concentrations in 2 species of palaeacanthocephalans. Also, Riggs et al. (1987) found elevated selenium concentrations in the cestode Bothriocephalus acheilognathi compared to 2 of its final hosts. One can conclude that fish parasites could be useful bioindicators of pollution in aquatic ecosystems.

\section{MATERIAL AND METHODS}

The infected eels used in this study were caught in October 1991 in the river Weser near Petershagen/ Schlüsselburg, Germany, by a professional fisherman. The viscera were immediately dissected with the aid of stainless steel scissors and forceps which had been previously cleaned with $1 \%$ ammonium EDTA-solution and double-distilled water. The bile and samples of liver and intestine were taken with the same instruments, as were the adults of Anguillicola crassus which were removed from the swimbladder and the acanthocephalans collected from the intestines. The tissues and parasites of 8 eels were used for individual investigations while the other samples were collective samples of helminths from 5 to 7 eels. The pooled samples served to compare the lead concentrations between small $(<2 \mathrm{~cm})$, large $(>2 \mathrm{~cm})$ and intermediate sized A. crassus.

After homogenization of the tissues and the parasites with a dispersing tool (Ultra Turrax), the sample material was decomposed as described by Kruse (1980). The resulting white salt was redissolved in $1 \mathrm{ml}$ 1:1000 diluted nitric acid and analysed for lead in a Perkin Elmer Model Z-3030 atomic absorption spectrometer 
equipped with an HGA-600 atomizer and a Zeeman effect background correction system. The accuracy of the analytical procedure was checked using standard reference material ZEBS no. 999948 (Agricultural Research Centre, Jokioinen, Finland). The metal concentrations in each sample were calculated from the corresponding regression lines (correlation factor $\geq 0.99$ ) using the standard addition method for each tissue and the parasites. For statistical analysis Fisher's least significance test was applied.

\section{RESULTS}

The detection limit $(3 \times \mathrm{SD}, \mathrm{n}=30)$ for lead was found to be $0.01 \mathrm{ppm}$; the average recovery for spiked samples of the fish tissues and the parasites ranged between 89 and 93\%. The lead concentrations in organs of eel and their parasites are summarized in Tables $1 \& 2$.

Anguillicola crassus contained the lowest lead levels, whereby the lead concentration of Paratenuisentis ambiguus seemed to be much higher than that of the nematode and also higher than that of all eel organs, although there is no statistical significance due to the low number of eels infected with $P$. ambiguus (Tables 1 $\& 2$ ). Comparing the eel organs, lead levels were highest in the liver and lowest in the bile

The mean lead levels found in the different size groups of Anguillicola crassus did not differ markedly from each other (Table 3) but were significantly ( $\mathrm{p}<$ 0.05 ) lower than in the respective collective samples of the acanthocephalan

The lead level in Paratenuisentis ambiguus was 185 times higher than that in Anguillicola crassus, 123 times higher than that of the bile, 41 times higher than that in the intestine and 21 times higher than that in the liver (Table 2).

Table 1. Lead concentrations ( $\mu \mathrm{g} \mathrm{g}^{-1}$ wet wt) in tissues of Anguilla anguilla and in parasites Anguillicola crassus and Paratenuisentis ambiguus. np; no parasites in the intestine na: not enough material to analyse

\begin{tabular}{|cccccc|}
$\begin{array}{c}\text { Eel } \\
\text { no. }\end{array}$ & Liver & Bile & Intestine & $\begin{array}{c}\text { A. } \\
\text { crassus }\end{array}$ & $\begin{array}{c}P . \\
\text { ambiguus }\end{array}$ \\
\hline 1 & 0.16 & 0.03 & 0.11 & 0.01 & $\mathrm{np}$ \\
2 & 0.15 & 0.05 & 0.12 & 0.03 & $\mathrm{np}$ \\
3 & 0.28 & 0.03 & 0.10 & 0.02 & 2.1 \\
4 & 0.17 & 0.02 & 0.12 & 0.01 & $\mathrm{np}$ \\
5 & 0.18 & na & 0.06 & 0.02 & $\mathrm{np}$ \\
6 & 0.15 & 0.02 & 0.08 & na & 5.6 \\
7 & 0.12 & 0.05 & 0.06 & 0.02 & np \\
8 & 0.25 & na & 0.09 & na & 3.6 \\
\hline
\end{tabular}

Table 2. Mean lead concentrations ( $\mu \mathrm{g} \mathrm{g}^{-1}$ wet wt) in tissues of Anguilla anguilla and in parasites Anguillicola crassus and Paratenuisentis ambiguus

\begin{tabular}{|lcccc|}
\hline Tissue & $\mathrm{n}$ & Mean & SD & Range \\
\hline Liver & 8 & 0.18 & 0.05 & $0.12-0.28$ \\
Bile & 6 & 0.03 & 0.01 & $0.02-0.05$ \\
Intestine & 8 & 0.09 & 0.03 & $0.06-0.12$ \\
A. crassus & 6 & 0.02 & 0.01 & $0.01-0.03$ \\
P. ambiguus & 3 & 3.7 & 1.7 & $2.1-5.6$ \\
\hline
\end{tabular}

Table 3. Lead concentrations ( $\mu \mathrm{g} \mathrm{g}^{-1}$ wet wt) in collective samples of Anguillicola crassus and Paratenuisentis ambiguus. -: below limit of guarantee of purity $(6 \times \mathrm{SD}$; Kaiser 1966)

\begin{tabular}{|ccccc|}
\hline $\begin{array}{c}\text { Sample } \\
\text { no. }\end{array}$ & $>2 \mathrm{~cm}$ & $\begin{array}{c}\text { A. crassus } \\
\sim 2 \mathrm{~cm}\end{array}$ & $<2 \mathrm{~cm}$ & P. ambiguus \\
\hline 1 & 0.02 & 0.01 & 0.01 & 3.2 \\
2 & 0.03 & 0.01 & - & 2.0 \\
3 & 0.02 & 0.02 & 0.01 & 2.7 \\
4 & 0.01 & 0.01 & 0.01 & 1.9 \\
5 & 0.02 & 0.02 & 0.01 & 2.4 \\
6 & 0.02 & 0.01 & 0.02 & 1.7 \\
Mean & 0.02 & 0.01 & 0.01 & 2.3 \\
SD & 0.01 & 0.01 & 0.01 & 0.6 \\
\hline
\end{tabular}

\section{DISCUSSION}

Compared to bile and intestinal tissue, the livers of the eels contained the highest amount of lead. This result had been expected as liver is considered to be the most important organ for lead accumulation in fish (e.g. Kruse \& Krüger 1986).

From the data presented here, one may conclude that the nematode Anguillicola crassus accumulates less lead than the organs of its final host eel. Thus, it seems to be possible that $A$. crassus, which feeds on blood and uses an aspartyl proteinase to degrade hemoglobin (Polzer \& Taraschewski 1993), is able to excrete heavy metals. The 3 size (age) groups of adult worms did not differ in this respect.

It is evident that the eoacanthocephalan Paratenuisentis ambiguus contained more than 20 -fold more lead than the livers of the eel, although only 3 individual samples were available. However, the pooled samples $(\mathrm{p}<0.05)$ significantly reveal a higher lead concentration in $P$. ambiguus compared to Anguillicola crassus. Recently Sures et al. (1994a, b) also reported very high lead concentrations in 2 palaeacanthocephalans: Acanthocephalus lucii (mean lead concentration: $11 \mathrm{~g} \mathrm{~g}^{-1}$ compared to $0.09 \mathrm{~g} \mathrm{~g}^{-1}$ in the liver of its host perch) and Pomphorhynchus laevis (mean lead con- 
centration: $54 \mathrm{~g} \mathrm{~g}^{-1}$ compared to $0.07 \mathrm{~g} \mathrm{~g}^{-1}$ in the liver of its host chub).

Thus, it seems to be a charasteristic feature of acanthocephalans to accumulate very high amounts of lead. Due to this accumulation capacity and to their abundance in different aquatic ecosystems, acanthocephalans may serve as rather useful indicators of lead contamination in the aquatic environment in addition to other indicator invertebrates. Concerning the role of fish-parasitizing nematodes as indicators for heavy metals, other species dwelling in the intestine or the body cavity should be investigated.

Acknowledgements. Thanks to Mr M. Reiter for providing naturally infected eels. We also thank Dr R. Kruse for providing equipment to decompose the samples.

\section{LITERATURE CITED}

Hamers, R., Lehmann, J., Mock, D., Taraschewski, H. (1992). In vitro study of the migratory and adherent response of fish leucocytes to the eel-pathogenic acanthocephalan Paratenuisentis ambiguus (van Cleave, 1921) Bullock et Samuel, 1975 (Eoacanthocephala: Tenuisentidae). J. Fish Shellfish Immunol. 2: 43-51

Hamers, R., Taraschewski, H., Lehmann, J., Mock, D. (1991). In vitro study on the impact of fish sera on survival and fine structure of the eel-pathogenic acanthocephalan Paratenuisentis ambiguus. Parasitol. Res. 77: 703-708

Kaiser, H. (1966). Zur Definition der Nachweisgrenze, der Garantiegrenze und der dabei benutzten Begriffe. Z anal. Chem. 216: 80-93

Khan, R. A., Thulin, J. (1991). Influence of pollution on parasites of aquatic animals. Adv. Parasitol. 30: 201-238

Koskivaara, M., Valtonen, E. T. (1992). Dactylogyrus (Monogenea) communities on the gills in three lakes in Central Finland Parasitol. 104: 263-272

Kruse, R. (1980). Vielfach-Bestimmung von $\mathrm{Pb}$ und $\mathrm{Cd}$ in Fischen durch elektrothermale AAS nach NaBveraschung in kommerziellen Teflonbechern. Z. Lebensm. Unters. Forsch. 171: 261-264

Responsible Subject Editor: O. Kinne, Oldendorf/Luhe, Germany
Kruse, R., Krüger, K.-E. (1986). Ergebnisse einer MonitoringStudie zur Verbreitung von Umweltkontaminanten in Fischen niedersächsischer Gewässer Lebensmittelchem. gerichtl. Chem. 40: 88-92

Moller, H. (1987). Pollution and parasitism in the aquatic environment. Int. J. Parasitol. 17: 353-361

Nagasawa, K. (1994). A bibliography of nematodes of the genus Anguillicola (Dracunculoidea: Anguillicolidae), swimbladder parasites of eel (Anguilla spp.): 1935-1993. Folia Parasitol. (in press)

Polzer, M., Taraschewski, H. (1993). Identification and characterization of the proteolytic enzymes in the developmental stages of the eel-pathogenic nematode Anguillicola crassus. Parasitol. Res. 79: 24-27

Riggs, M. R., Lemly, A. D., Esch, G. W. (1987). The growth, biomass, and fecundity of Bothriocephalus acheilognathi in a North Carolina cooling reservoir. J. Parasitol. 73: $893-900$

Samuel, G., Bullock, W. L. (1981). Life cycle of Paratenuisentis ambiguus (Van Cleave, 1921) Bullock and Samuel, 1975 (Acanthocephala: Tenuisentidae). J. Parasitol. 67 : $214-217$

Sures, B., Taraschewski, H., Jackwerth, E. (1994a). Comparative study of lead accumulation in different organs of perch (Perca fluviatilis) and its intestinal parasite Acanthocephalus lucii. Bull. environ. Contam. Toxicol. 52: 269-273

Sures, B., Taraschewski, H., Jackwerth, E. (1994b). Lead accumulation in Pomphorhynchus laevis and its host. J. Parasitol. 80: 355-357

Taraschewski, H., Moravec, F., Lamah, T., Anders, K. (1987). Distribution of two helminths recently introduced into European eel populations: Anguillicola crassus (Nematoda, Dracunculoidea) and Paratenuisentis ambiguus (Acanthocephala, Tenuisentidae). Dis. aquat. Org. 3: $167-176$

Taraschewski, H. (1989). Host-parasite interface of Paratenuisentis ambiguus (Eoacanthocephala) in naturally infected eel and in laboratory-infected sticklebacks and juvenile carp and rainbow trout. J. Parasitol. 75: 911-919

Taraschewski, H., Peters, W., Latka, I. (1992). Comparative investigations of the morphology and chemical composition of the eggshells of acanthocephala. Parasitol. Res. 78 : $382-387$

Manuscript first received: February 15, 1994

Revised version accepted: April 29, 1994 